Article

\title{
Study on Polymer Electrolyte Fuel Cells with Nonhumidification Using Metal Foam in Dead-Ended Operation
}

\author{
Myo-Eun Kim ${ }^{1,2}$ and Young-Jun Sohn ${ }^{1,2, *}$ \\ 1 Fuel Cell Laboratory, New and Renewable Energy Research Division, Korea Institute of Energy Research, \\ Daejeon 34129, Korea; monicakim@kier.re.kr \\ 2 Advanced Energy and System Engineering, University of Science and Technology, Daejeon 34113, Korea \\ * Correspondence: yjsohn@kier.re.kr; Tel.: +82-42-860-3087; Fax: +82-42-860-3104
}

Received: 23 January 2020; Accepted: 4 March 2020; Published: 7 March 2020

\begin{abstract}
Portable power sources have attracted increasing interest and attention, with a focus on the reduction of the system volume. Thus, portable power sources often use polymer electrolyte fuel cell (PEFC) systems with dead-ended operation-which are simpler and more fuel-efficient than conventional PEFC systems. In these systems, the fuel may be supplied under nonhumidified conditions to minimize the balance of plant (BOP). In recent studies, metal foams have been used as flow fields to improve fuel diffusion and water management in the PEFC; the performance can be compared to that of a conventional channel. This study compared the performance and water management ability of channel and metal foam flow fields under nonhumidified conditions with dead-ended operation. The results demonstrate that the average output was similar for both flow fields. In terms of fuel efficiency, the PEFC with the metal foam could be operated for a significantly longer time without purging than that with the channel.
\end{abstract}

Keywords: polymer electrolyte fuel cell; portable power source; metal foam; dead-ended operation; water management

\section{Introduction}

Interest in drones, wearable robots, and unmanned aerial vehicles (UAVs) has been increasing worldwide in recent years. The increasing use of such devices has led to an increased demand for portable power. Until now, batteries have been the most popular portable power sources. However, batteries are disadvantageous because of their low energy density and long charging times relative to their capacity. Therefore, researchers and engineers are considering fuel cells as an alternative next-generation portable energy source [1-6].

Among fuel cells, polymer electrolyte fuel cells (PEFCs) are suitable as a portable power source owing to their low operating temperature, high energy density, and because they are ecofriendly. In addition, compared to a battery, the efficiency of a fuel cell is unaffected by the device size and its operation time can be increased in proportion to the fuel amount, thereby enabling usage for long periods without increasing the fuel cell system size. These properties make PEFCs efficient and suitable energy sources for small electric devices. PEFCs have been applied to vehicles such as automobiles and UAVs. Fuel cell cars are already being commercially manufactured and used. In addition, active technological developments are underway for possible military and outdoor applications. [7-12].

The most important requirements for portable power are the simplicity of the fuel cell system and fuel efficiency. Generally, the complexity of typical PEFC systems increases owing to humidification and fuel recirculation parts. By contrast, systems operating without humidification involve a simple 
design that eliminates the humidifier and recirculation subsystem, resulting in dead-ended operation. In dead-ended operation, the parasitic losses can be reduced by simplifying the system. In particular, in the mobility system, excessive weight can reduce the efficiency of the system. So, efficiency of the system can be enhanced by reducing the weight of the system. It contributes to improvement in fuel efficiency. This simple way of improving fuel efficiency is well-suited for portable power sources.

Experimental studies have tried to optimize fuel cell systems for portable power sources. In dead-ended operation, the anode outlet is always closed; therefore, by maintaining a constant pressure at the inlet using a pressure regulator, an adequate amount of hydrogen can be supplied for the chemical reaction to produce the required electric load. This fuel supply mechanism yields a nearly $100 \%$ fuel efficiency. In addition, the dead-ended operating system has many advantages, including relative simplicity, low parasitic power, easy control, and a low weight, volume, and manufacturing cost. Thus, this system is often applied to vehicles and portable power generation devices [13-19].

However, in the dead-ended operation system, the blocked outlet causes the diffusion of impurities like water and nitrogen inside the cell from the cathode to the anode and accumulation in the anode's flow field. This reduces the concentration of hydrogen and active sites for electrochemical reactions, causing further flooding. These phenomena gradually degrade the fuel cell's performance [20]. To solve this problem, a solenoid valve is installed at the anode outlet for purging impurities under specified conditions.

For dead-ended systems for portable power without humidification and recirculation, many parameters have to be considered, such as purge strategy, humidity, or temperature control. Especially, water management research is very important and needed.

Most existing studies on dead-ended operation systems have focused on their operating conditions [21-26] and optimizing purging strategies [27-30]. Yang et al. [31] compared the performance of dead-ended systems according to channel-type flow fields. Previous studies commonly tried to manage water efficiently in dead-ended operating modes, because efficient water management is an especially important issue in dead-ended operation.

Recent studies have used metal foam as fuel cell flow fields to improve the PEFC performance, especially in terms of gas distribution and water management [32-42]. These studies have shown that the properties of metal foam, including high porosity, low permeability, and high tortuosity [33,40], homogenize the flow distribution and improve water management. An advantage of metal foam is that it lacks a rib and channel structure compared with conventional channel-type flow fields. This structural feature promotes gas/water distribution in the in-plane direction of the fuel cell and produces an even local current distribution accordingly [40]. Tabe et al. [41] reported that a PEFC with metal foam as a flow distributor exhibits good performance, especially under low-humidity conditions. Moreover, some studies made contributions to channel flooding and porous media flow fields [42-46].

When operating in the dead-ended mode with channel-type flow fields, a significant amount of water accumulates at the end of the flow channel in the gas flow direction [21]. However, metal foam enables many flow paths owing to its porous structure. The water and gases may be assumed to be evenly distributed in various directions within the metal foam [33].

However, although many studies have reported improved water management when using metal foam, studies on the application of metal foam in dead-ended operation are lacking. Therefore, the present study proposes a nonhumidified PEFC system with dead-ended operation to simplify the fuel cell system and enhance fuel efficiency.

\section{Experiments}

\subsection{Experimental Setup}

Figure 1a shows the operating system for the fuel cell's performance test. The system comprised fuel supply, electrical and temperature control, and data acquisition and control parts. In the fuel supply part, hydrogen of $99.9 \%$ purity was supplied from the gas cylinder and air was supplied from 
the air compressor. For flow-through operation, a mass flow controller was installed to adjust the flow rate and, thereby, ensure that enough fuel was supplied to the load. An analog pressure regulator was installed at the front of the anode to maintain the fuel supply pressure at 0.5 bar for the dead-ended operation. A gas-to-liquid-type membrane humidifier was used, as necessary, as an external humidifier for gas humidification.

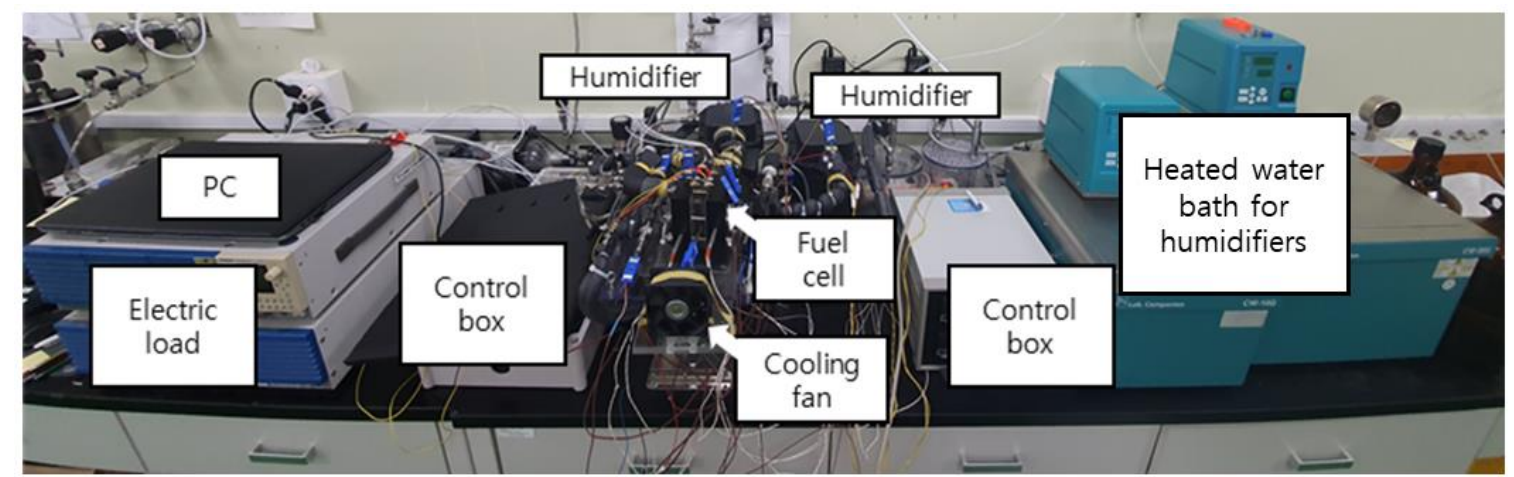

(a)

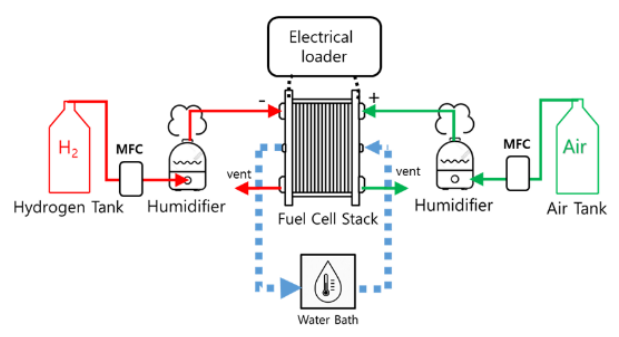

(b)

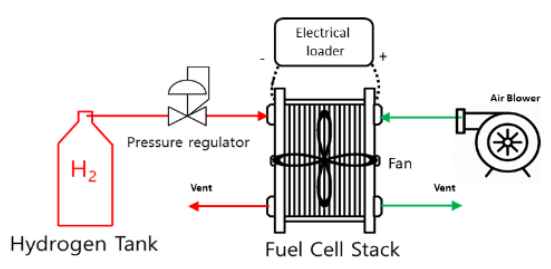

(c)

Figure 1. (a) Experimental setup for the performance test. (b) Schematic of flow-through operation. (c) Schematic of dead-ended operation.

The electrical components consisted of the fuel cell (Figure 2a) for generating electricity and a Kikusui PLW-664 model electric loader for consuming electricity.

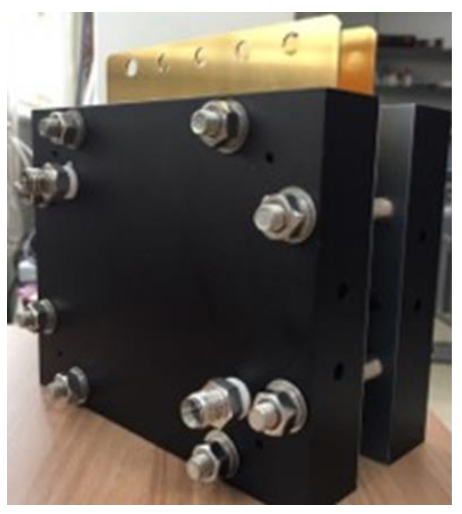

(a)

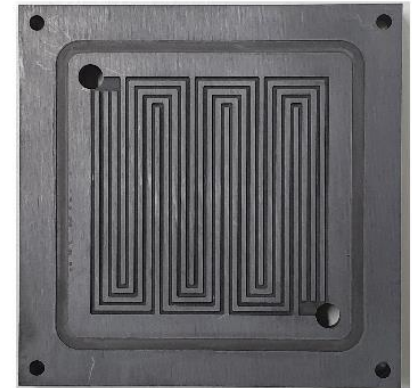

(b)

Figure 2. Cont. 


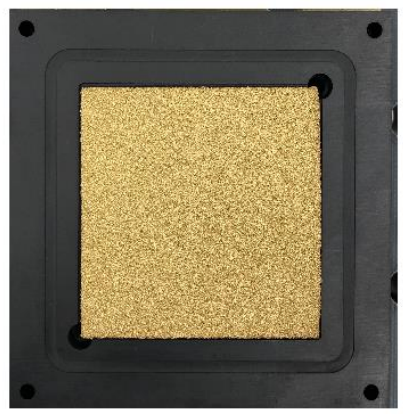

(c)

Figure 2. (a) A $25 \mathrm{~cm}^{2}$ polymer electrolyte fuel cell (PEFC) single cell. (b) Four-channel serpentine flow field. (c) Metal foam flow field.

Two types of channels and metal foams were applied as flow fields. The general channel-type flow field took the form of a 4-channel serpentine in the widely used graphite separator. Metal foams were selected through a metal foam optimization study, as described in our previous work [47]. This involved a gold-coated nickel foam compressed to $0.5 \mathrm{~mm}$ (compression ratio of $25 \%$ ) and inserted into a graphite separator as a chamber. Figure $2 b, c$ show the serpentine channel and metal foam flow fields, respectively.

Figure 3 shows a scanning electron microscopy (SEM) image of the metal foam. The SEM image and mercury $(\mathrm{Hg})$ porosimetry data plotted in Figure 4 show the pore structure and uniform pore distribution of the metal foam.

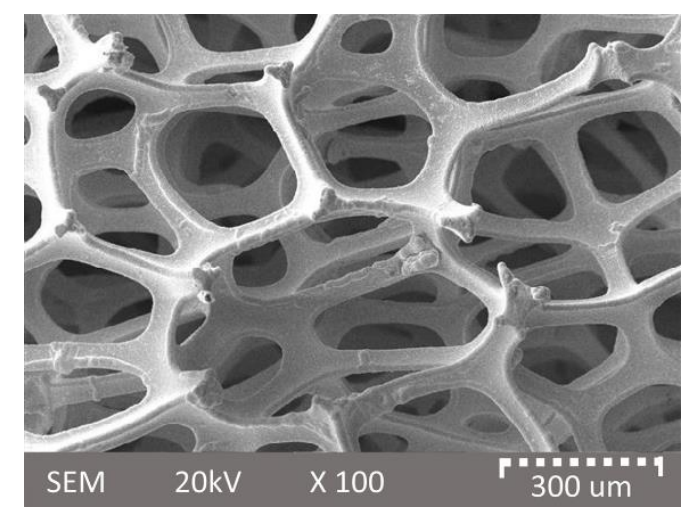

Figure 3. Scanning electron microscopy (SEM) image of metal foam. 


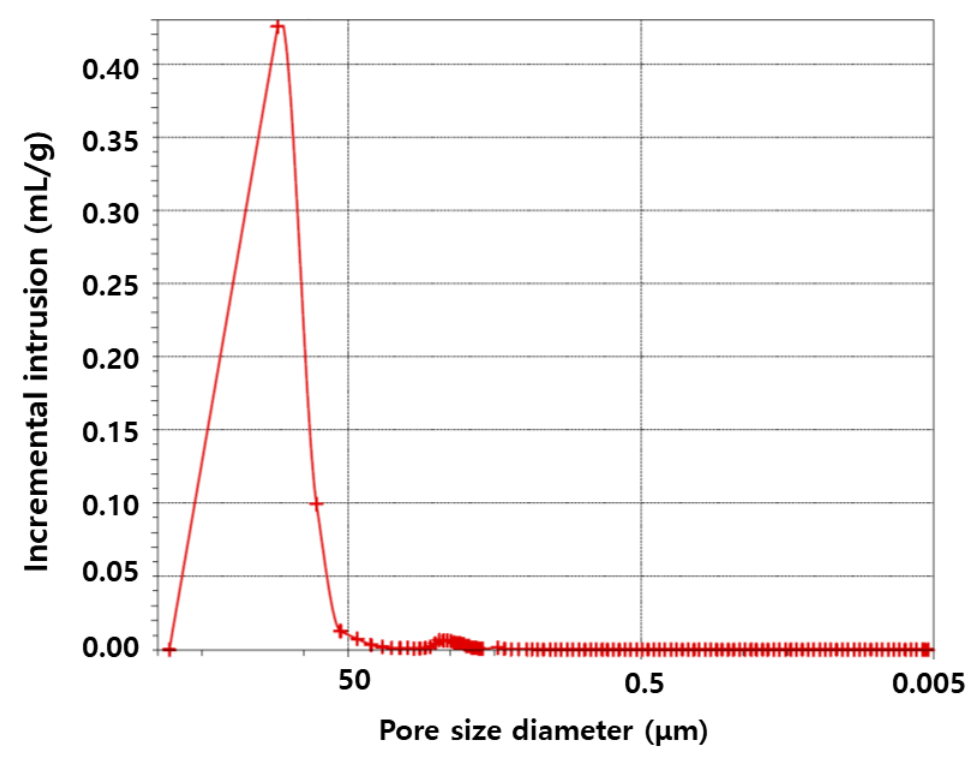

Figure 4. Incremental intrusion vs. pore size of metal foam.

The fuel cell had an active area of $25 \mathrm{~cm}^{2}$ with GORE ${ }^{\circledR}$ PRIMEA ${ }^{\circledR}$ MEAs A510.1/M665.15/C580.4 and SIGRACET ${ }^{\circledR}$ 10BC GDL. The air-cooling system was applied to the temperature control part to simplify the system, with the cooling and heating operated alternately to maintain the operating temperature of the cell at $60^{\circ} \mathrm{C}$. The data acquisition and control parts were controlled using the National Instruments' compact DAQ 9178 and LabView programs to record operating parameters like temperature, pressure, cell potential, and output current.

Figure $1 b, c$ show schematics of the flow-through (FT) and dead-ended (DE) modes, respectively. The FT system was clearly more complex than the DE system. If a recirculation part was included to improve fuel efficiency, the difference in system volume was higher than that of our targeted nonhumidified dead-ended PEFC system. The properties of the fuel cell configuration and operating conditions are listed in Table 1.

Table 1. Properties of fuel cell configuration and operating conditions.

\begin{tabular}{|c|c|c|c|}
\hline \multicolumn{4}{|c|}{ Properties of Fuel Cell Configuration } \\
\hline \multicolumn{2}{|c|}{ 4-Channel Serpentine Flow Field } & \multicolumn{2}{|c|}{ Metal Foam Type Flow Field } \\
\hline Active area & $25 \mathrm{~cm}^{2}$ & Active area & $25 \mathrm{~cm}^{2}$ \\
\hline Width of channel & $1.0 \mathrm{~mm}$ & $\begin{array}{l}\text { Thickness of metal foam } \\
\text { (compressed) }\end{array}$ & $0.5 \mathrm{~mm}$ \\
\hline Height of channel & $0.8 \mathrm{~mm}$ & $\begin{array}{l}\text { Porosity of metal foam } \\
\quad \text { (compressed) }\end{array}$ & $76.79 \%$ \\
\hline Width of rib & $1.0 \mathrm{~mm}$ & Hydrophobicity & $\begin{array}{c}\text { Hydrophobic } \\
\left(\text { contact angle }=95.8^{\circ}\right)[48]\end{array}$ \\
\hline \multicolumn{4}{|c|}{ Operating Condition } \\
\hline \multicolumn{2}{|c|}{ Flow Through Operation Mode } & \multicolumn{2}{|c|}{ Dead-Ended Operation Mode } \\
\hline $\begin{array}{l}\text { Operating } \\
\text { temperature }\end{array}$ & $60{ }^{\circ} \mathrm{C}$ & Operating temperature & $60{ }^{\circ} \mathrm{C}$ \\
\hline $\begin{array}{l}\text { Relative humidity } \\
\text { (if necessary) }\end{array}$ & $100 \%$ & Current (CC mode) & $30 \mathrm{~A}$ \\
\hline $\begin{array}{l}\text { Stoichiometric ratio } \\
\text { An/Ca }\end{array}$ & $1.2 / 2.5$ & Fuel supply pressure & 0.5 bar \\
\hline
\end{tabular}




\subsection{Experimental Conditions}

First, the suitability of each flow field type for nonhumidified operation was investigated and confirmed. To compare the water management characteristics of each channel and metal foam flow field type through the polarization curve (i-V curve) at low and high current densities, an evaluation operation was performed in the FT mode.

The FT mode involved a constant-voltage operation to produce a polarization curve by measuring the current in the range of the cell potential from the open circuit voltage (OCV) to $0.4 \mathrm{~V}$. The stoichiometric ratios for the anode and cathode were 1.2 and 2.5, respectively, to prevent fuel starvation. Each flow field was operated under four humidification conditions-dry (DR), only anode humidified $(\mathrm{AH})$, only cathode humidified $(\mathrm{CH})$, and both humidified $(\mathrm{BH})$. Then, the performance and water management ability of the channel and metal foam type flow fields were compared in the nonhumidified dead-ended operation system, allowing optimization for simplifying the system and improving fuel efficiency.

In the DE mode, cell potentials were measured over time through constant-current operation at $30 \mathrm{~A}$ (current density $=1.2 \mathrm{~A} / \mathrm{cm}^{2}$ ). In general, the voltage in the DE mode decreased gradually, owing to water and impurities that accumulated during operation.

Figure 5 shows a plot of the typical voltage with time for dead-ended operation. As shown in this figure, the purge interval is defined as the duration between consecutive purge valve openings, and the purge duration is the duration for which the purge valve is open during each purge. Further, the limit voltage is defined as the voltage at which the purge valve is opened.

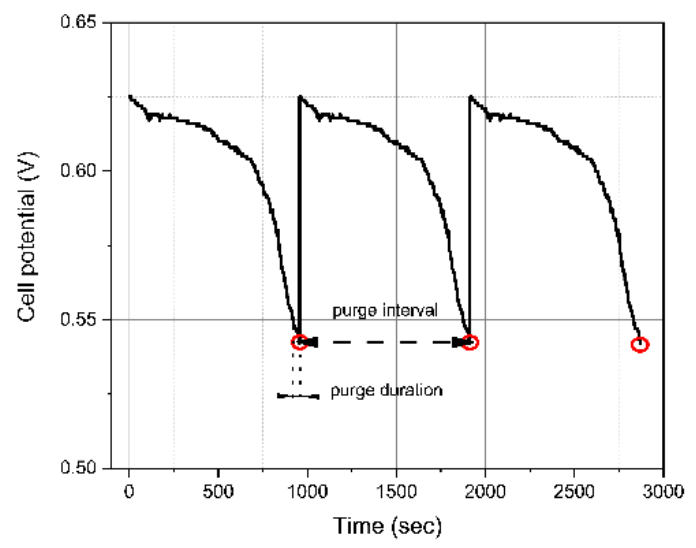

Figure 5. Typical variation of voltage with operation time for dead-ended operation.

When the cell potential reached the limit voltage, purging occurred and removed the accumulated water and impurities, thereby enabling the voltage to recover. This process was repeated throughout the DE operation, with the limit voltage set to $0.55 \mathrm{~V}$ to prevent excessive performance degradation.

\section{Results and Discussion}

\subsection{Suitability for Nonhumidified Operation}

Figures 6 and 7, respectively, show the polarization curves of the PEFC using a general serpentine channel and metal foam as flow fields under various humidification conditions. 


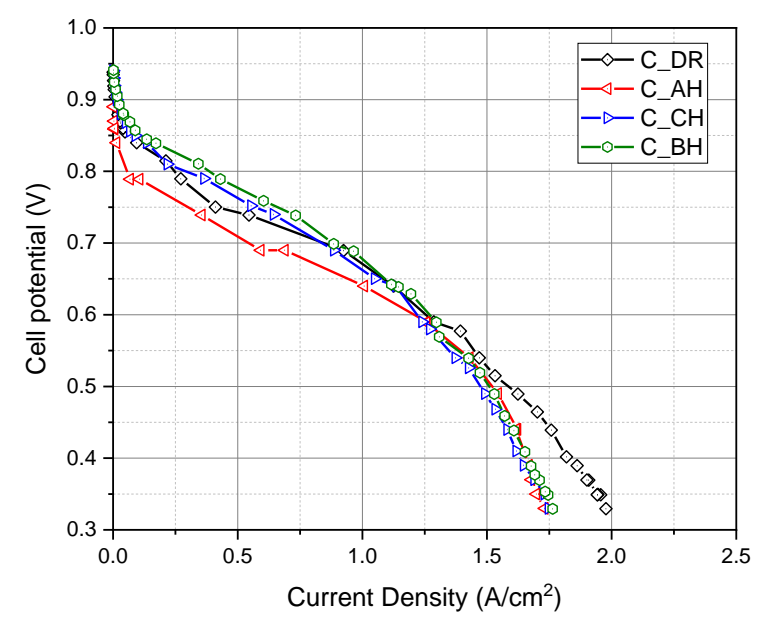

Figure 6. Variation of PEFC voltage with channels for various humidification conditions.

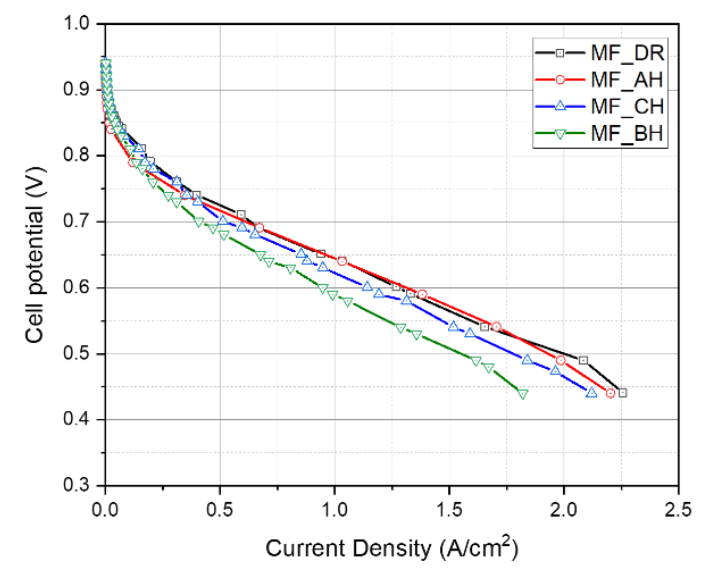

Figure 7. Variation of PEFC voltage with metal foam flow field under various humidification conditions.

In Figure 6, at low current densities, a PEFC with a serpentine channel under the BH condition (C-BH) exhibited the best performance, whereas one under the DR condition (C-DR) showed the worst performance. This is because humidification increases the membrane hydration, thus helping to improve the ionic conductivity of the membrane. However, at higher current densities, the performance became similar and decreased rapidly. This was likely due to flooding or fuel starvation within the cell. However, because enough fuel was supplied, the performance decrease is attributed to flooding alone.

Figure 7 shows the results of the same experiment when performed using metal foams as the flow field. The PEFC exhibited a similar overall performance at ultralow current density, irrespective of the humidification condition. At a low current density, no significant difference in performance was seen compared to that of the PEFC using the channel-type flow field. The PEFC with metal foam performed better under the conditions of nonhumidification (MF-DR) and only anode humidification (MF-AH). This was because the water produced from the cathode diffused through the membrane via back-diffusion and spread evenly in the anode flow field, thus lowering the ionic resistance of the membrane and resulting in an even self-humidification. In the PEFC with metal foam, no sudden potential drop occurred in the high-current-density region, where mass transfer loss was dominant. This was due to the structural properties of the metal foam, which prevent flooding due to the uniform distribution of water in the foam.

Figure 8 shows a comparison of the PEFC with the flow field channel under fully humidified conditions (C-BH) and that with the metal foam under dry conditions (MF-DR). The results reveal a similar or better performance for the cell with the metal foam in the high-current-density region 
$\left(>1 \mathrm{~A} / \mathrm{cm}^{2}\right)$. Thus, to simplify the system, the metal foam is well-suited as a flow field for nonhumidified operating conditions.

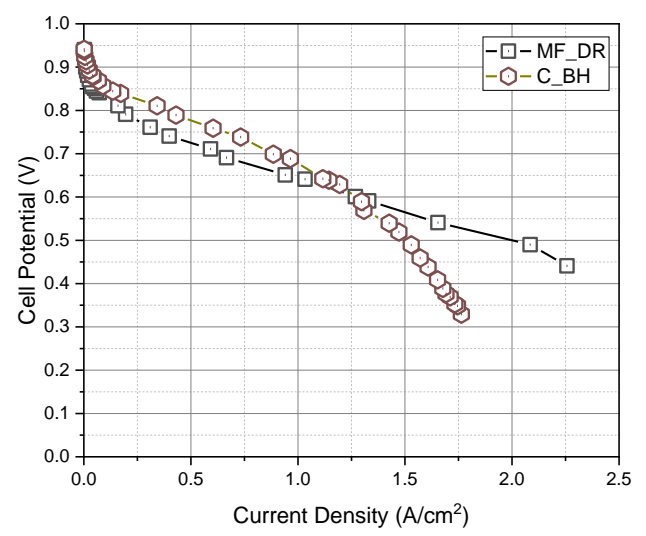

Figure 8. Comparison of PEFC voltage variations with channel under BH and metal foam under DR humidification conditions.

\subsection{Effect of Metal Foam on the Optimized System for Portable Power}

The optimized system for portable power was one with dead-ended operation under nonhumidified conditions. The dead-ended operation was conducted at a constant current of 30 A. Figure 9 shows separate plots of the voltage variations of each purge cycle.

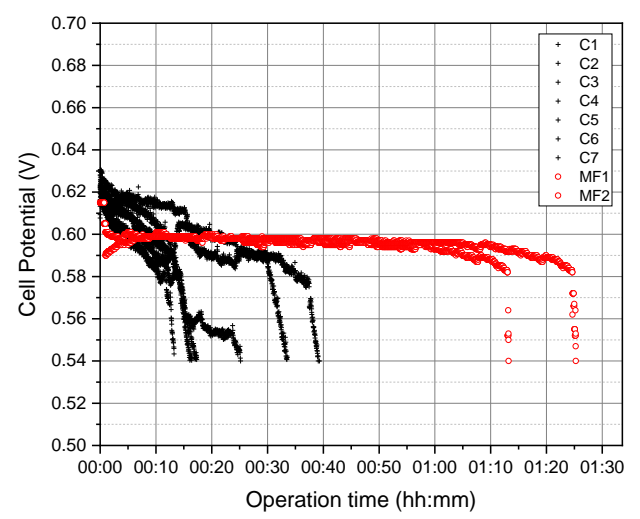

Figure 9. Voltage variations of each purge cycle (C1-C7, channel; MF1-MF2, metal foam).

As shown in Figure 9, the PEFC with a channel-type flow field (black line, C1-C7) showed a very high voltage fluctuation, and the purge interval was unstable. However, the PEFC with a metal-foam-type flow field (red line, MF1 and MF2) showed a sudden voltage drop immediately after purging and performed stably with a constant voltage compared to the channel-type PEFC. Figure 10 shows the voltage variations during operation for more than $2 \mathrm{~h}$. 


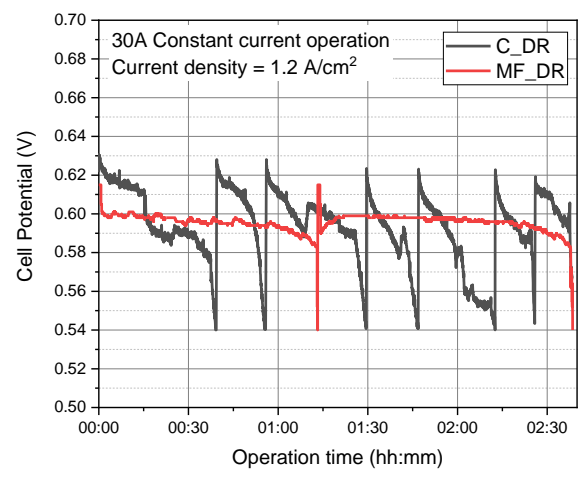

Figure 10. Voltage variations during long-term operation.

The average voltages of the PEFC with the channel and the metal foam were similar, being 0.594 and $0.599 \mathrm{~V}$, respectively, whereas the purge frequencies differed by a factor of more than three. Despite the unstable purge interval, the operation of the PEFC with the metal foam produced purge intervals surpassing those of the PEFC with the channel by a minimum of 2.17 and a maximum of 6.86 times, and these parameters affected the hydrogen losses, which directly influenced the fuel efficiency.

Equation (1) gives the amount of hydrogen consumed for electricity generation [49], where $i$ is the current generated by the fuel cell [A], $\mathrm{F}$ is the Faraday constant $[\mathrm{C} / \mathrm{mol}]$, and $\mathrm{n}$ is the number of moles of electrons transferred (for $\mathrm{H}_{2}, \mathrm{n}=2$ ).

$$
H_{2} \text { usage }=\frac{i}{2 F}\left[\frac{\mathrm{mol}}{\mathrm{s}}\right]
$$

The stoichiometric ratio $(\lambda)$ is assumed to be 1, except for the purge duration in the dead-ended operation. The mass flow rate $\left(v_{f u e l}\right)$ of the fuel can be calculated using Equation (2). If purges occur often, $\lambda$ is larger and $v_{f u e l}$ also increases. Then, the fuel utilization efficiency $\varepsilon_{\text {fuel }}$ (Equation (3)) decreases [50].

$$
\begin{gathered}
v_{f u e l}=H_{2} \text { usage } \times \lambda\left[\frac{\mathrm{mol}}{\mathrm{s}}\right] \\
\varepsilon_{\text {fuel }}=\frac{i / n F}{v_{\text {fuel }}}=\frac{1}{\lambda}
\end{gathered}
$$

In addition, Figure 11 shows the channel-type flow field after dead-ended operation; the cell was dismantled to check the flow field. Consequently, water aggregation at the end of the outlet side was confirmed. This highlights that the expected gradual accumulation at the end of the channel was the cause of flooding.

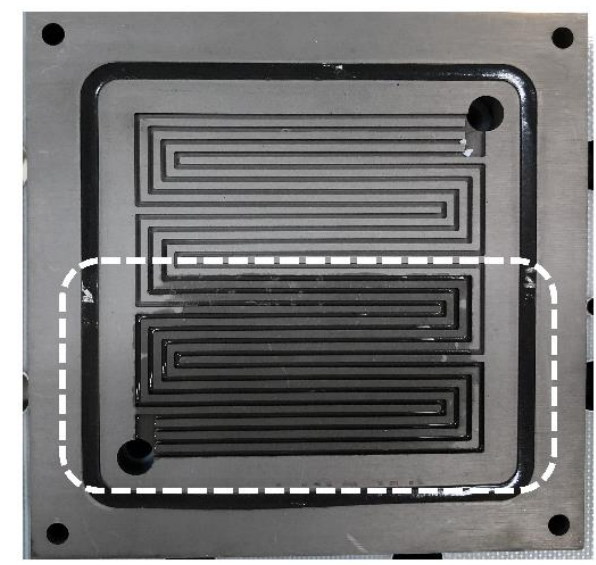

Figure 11. Channel-type flow field after dead-ended operation (anode side). 


\section{Conclusions}

This study investigated a possible optimizing method for a portable power source system. We suggested simplifying a portable power system and improving its fuel efficiency. To achieve these goals, we conducted experiments on a nonhumidified PEFC system with dead-ended operation to simplify the system and enhance its fuel efficiency.

The assessment results for the suitability of nonhumidified operation with channel and metal foam flow fields demonstrated that in the high-current-density region $\left(>1 \mathrm{~A} / \mathrm{cm}^{2}\right)$, the performance of the system with the metal foam was similar or better. This verifies the suitability of the metal foam as a flow field under nonhumidified operating conditions for simplifying the system. Then, the performance and water management ability of the channel and metal foam flow fields were compared for the nonhumidified dead-ended operation system. The results demonstrate that the average output energy was similar for both flow fields.

In terms of fuel efficiency, the PEFC with the metal foam could be operated longer than that with the channel, reaching a maximum of a 6.86 times higher operating time without purging. Thus, the purge frequency was also low. This indicates that the PEFC with the metal foam flow field under nonhumidified dead-ended operation will be a better alternative power source, owing to its simplicity and fuel efficiency. Dead-ended systems should be further studied in terms of water management, and the possibility of membrane degradation should also be taken into account. In addition, research on fuel loss efficiency is being conducted separately.

Author Contributions: M.-E.K. and Y.-J.S. conceived and conducted the experiments. M.-E.K. performed data management. M.-E.K. wrote and edited manuscript. Y.-J.S supervised the work. All authors have read and agreed to the published version of the manuscript.

Funding: This research and APC were funded by the Korea Institute of Energy Technology Evaluation and Planning (KETEP), grant number 20193010032490 "Development of $25 \mathrm{~kW}$ modular fuel cell power conversion system adopted dual converter technology".

Conflicts of Interest: The authors declare no conflict of interest.

\section{References}

1. Heinzel, A.; Hebling, C.; Müller, M.; Zedda, M.; Müller, C. Fuel cells for low power applications. J. Power Sources 2002, 105, 250-255. [CrossRef]

2. Meyers, J.P.; Maynard, H.L. Design considerations for miniaturized PEM fuel cells. J. Power Sources 2002, 109, 76-88. [CrossRef]

3. Chang, H.; Kim, J.R.; Cho, J.H.; Kim, H.K.; Choi, K.H. Materials and processes for small fuel cells. Solid State Ion. 2002, 148, 601-606. [CrossRef]

4. Wang, Y.; Chen, K.S.; Mishler, J.; Cho, S.C.; Adroher, X.C. A review of polymer electrolyte membrane fuel cells: Technology, applications, and needs on fundamental research. Appl. Energy 2011, 88, 981-1007. [CrossRef]

5. Giddey, S.; Badwal, S.P.S.; Ciacchi, F.T.; Fini, D.; Sexton, B.A.; Glenn, F.; Leech, P.W. Investigations on fabrication and lifetime performance of self - air breathing direct hydrogen micro fuel cells. Int. J. Hydrogen Energy 2010, 35, 2506-2516. [CrossRef]

6. Achmad, F.; Kamarudin, S.K.; Daud, W.R.W.; Majlan, E.H. Passive direct methanol fuel cells for portable electronic devices. Appl. Energy 2011, 88, 1681-1689. [CrossRef]

7. Wilberforce, T.; Alaswad, A.; Palumbo, A.; Dassisti, M.; Olabi, A.G. Advances in stationary and portable fuel cell applications. Int. J. Hydrogen Energy 2016, 41, 16509-16522. [CrossRef]

8. Hsu, F.K.; Lee, M.S.; Lin, C.C.; Lin, Y.K.; Hsu, W.T. A flexible portable proton exchange membrane fuel cell. J. Power Sources 2012, 219, 180-187. [CrossRef]

9. Oszcipok, M.; Zedda, M.; Hesselmann, J.; Huppmann, M.; Wodrich, M.; Junghardt, M.; Hebling, C. Portable proton exchange membrane fuel-cell systems for outdoor applications. J. Power Sources 2006, 157, 666-673. [CrossRef] 
10. Kundu, P.P.; Dutta, K. 6-Hydrogen Fuel Cells for Portable Applications. In Woodhead Publishing Series in Energy, Compendium of Hydrogen Energy; Michael, B., Angelo, B., Nejat Veziroğlu, T., Eds.; Woodhead Publishing: Cambridge, UK, 2016.

11. Cacciola, G.; Antonucci, V.; Freni, S. Technology up date and new strategies on fuel cells. J. Power Sources 2001, 100, 67-79. [CrossRef]

12. Voss, H.; Huff, J. Portable fuel cell power generator. J. Power Sources 1997, 65, 155-158. [CrossRef]

13. Yang, C.N.; Kim, Y.D. Development and Demonstration of 150W Fuel Cell Propulsion System for Unmanned Aerial Vehicle (UAV). Trans. Korean Hydrog. New Energy Soc. 2012, 23, 300-309. [CrossRef]

14. Inman, K.; Ahmad, Z.; Shi, Z.; Wang, X. Design of a proton exchange membrane portable fuel cell system for the 1st international association for hydrogen energy design competition. Int. J. Hydrogen Energy 2011, 36, 13868-13874. [CrossRef]

15. Hikita, S.; Nakamani, F.; Yamane, K.; Takagi, Y. Power-generation characteristics of hydrogen fuel cell with dead-end system. JSAE Rev. 2002, 23, 177-182. [CrossRef]

16. Wang, J.; Xiao, D. Development and Evaluation of a Portable Fuel Cell Hybrid System; Chinese Automation Congress (CAC): Xi'an, China, 2018.

17. Hwang, J.-J. Effect of hydrogen delivery schemes on fuel cell efficiency. J. Power Sources 2013, 239, 54-63. [CrossRef]

18. Himanen, O.; Hottinen, T.; Tuurala, S. Operation of a planar free-breathing PEMFC in a dead-end mode. Electrochem. Commun. 2007, 9, 891-894. [CrossRef]

19. Dumercy, L.; Pera, M.C.; Glises, R.; Hissel, D.; Hamandi, S.; Badin, F. PEFC stack operating in anodic dead end mode. Fuel Cells 2004, 4, 352-357. [CrossRef]

20. Li, H.; Tang, Y.; Wang, Z.; Shi, Z.; Wu, S.; Song, D.; Zhang, J.; Fatih, K.; Zhang, J.; Wang, H.; et al. A review of water flooding issues in the proton exchange membrane fuel cell. J. Power Sources 2008, 178, 103-117. [CrossRef]

21. Lee, Y.; Kim, B.; Kim, Y. An experimental study on water transport through the membrane of a PEFC operating in the dead-end mode. Int. J. Hydrogen Energy 2009, 34, 7768-7779. [CrossRef]

22. Siegel, J.B.; McKay, D.A.; Stefanopoulou, A.G.; Hussey, D.S.; Jacobson, D.L. Measurement of liquid water accumulation in a PEMFC with dead-ended anode. J. Electrochem. Soc. 2008, 155, 1168-1178. [CrossRef]

23. Sasmito, A.P.; Ali, M.I.; Shamim, T. A factorial study to investigate the purging effect on the performance of a dead-end anode PEM fuel cell stack. Fuel Cells 2015, 15, 160-169. [CrossRef]

24. Yang, C.W.; Chen, Y.S. A mathematical model to study the performance of a proton exchange membrane fuel cell in a dead-ended anode mode. Appl. Energy 2014, 130, 113-121. [CrossRef]

25. Gomez, A.; Raj, A.; Sasmito, A.P.; Shamim, T. Effect of operating parameters on the transient performance of a polymer electrolyte membrane fuel cell stack with a dead-end anode. Appl. Energy 2014, 130, 692-701. [CrossRef]

26. Yang, Y.; Zhang, X.; Guo, L.; Liu, H. Overall and local effects of operating conditions in PEM fuel cells with dead-ended anode. Int. J. Hydrogen Energy 2017, 42, 4690-4698. [CrossRef]

27. Chen, Y.S.; Yang, C.W.; Lee, J.Y. Implementation and evaluation for anode purging of a fuel cell based on nitrogen concentration. Appl. Energy 2014, 113, 1519-1524. [CrossRef]

28. Nikiforow, K.; Karimaki, H.; Keranen, T.M.; Ihonen, J. Optimization study of purge cycle in proton exchange membrane fuel cell system. J. Power Sources 2013, 238, 336-344. [CrossRef]

29. Lin, Y.F.; Chen, Y.S. Experimental study on the optimal purge duration of a proton exchange membrane fuel cell with a dead-ended anode. J. Power Sources 2017, 340, 176-182. [CrossRef]

30. Gomez, A.G.; Sasmito, A.P.; Shamim, T. Investigation of the purging effect on the performance of dead-end anode PEM fuel cell vehicle: A driving cycle test. ECS Trans. 2013, 58, 229-242. [CrossRef]

31. Yang, Y.; Zhang, X.; Guo, L.; Liu, H. Different flow fields, operation modes and designs for proton exchange membrane fuel cells with dead-ended anode. Int. J. Hydrogen Energy 2018, 43, 1769-1780. [CrossRef]

32. Carton, J.G.; Olabi, A.G. Three-dimensional proton exchange membrane fuel cell model: Comparison of double channel and open pore cellular foam flow plates. Energy 2017, 136, 185-195. [CrossRef]

33. Carton, J.G.; Olabi, A.G. Representative model and flow characteristics of open pore cellular foam and potential use in proton exchange membrane fuel cells. Int. J. Hydrogen Energy 2015, 40, 5726-5738. [CrossRef]

34. Chen, R.; Zhao, T.S. Porous current collectors for passive direct methanol fuel cells. Electrochim. Acta 2007, 52, 4317-4324. [CrossRef] 
35. Bao, Z.; Niu, Z.; Jiao, K. Numerical simulation for metal foam two-phase flow field of proton exchange membrane fuel cell. Int. J. Hydrogen Energy 2019, 44, 6229-6244. [CrossRef]

36. Huo, S. Experimental investigation on PEM fuel cell cold start behavior containing porous metal foam as cathode flow distributor. Appl. Energy 2017, 203, 101-114. [CrossRef]

37. Tseng, C.-J. A PEM fuel cell with metal foam as flow distributor. Energy Convers. Manag. 2012, 62, $14-21$. [CrossRef]

38. Tsai, B.-T. Effects of flow field design on the performance of a PEM fuel cell with metal foam as the flow distributor. Int. J. Hydrogen Energy 2012, 37, 13060-13066. [CrossRef]

39. Kumar, A.; Reddy, R.G. Modeling of polymer electrolyte membrane fuel cell with metal foam in the flow-field of the bipolar/end plates. J. Power Sources 2003, 114, 54-62. [CrossRef]

40. Kumar, A.R. Materials and design development for bipolar/end plates in fuel cells. J. Power Sources 2004, 29, 62-67. [CrossRef]

41. Tabe, Y. Performance characteristics and internal phenomena of polymer electrolyte membrane fuel cell with porous flow field. J. Power Sources 2013, 238, 21-28. [CrossRef]

42. Wang, Y. Porous-media flow fields for polymer electrolyte fuel cells I. Low humidity operation. J. Electrochem. Soc. 2009, 156, B1124-B1133. [CrossRef]

43. Wang, Y. Porous-media flow fields for polymer electrolyte fuel cells II. Analysis of channel two-phase flow. J. Electrochem. Soc. 2009, 156, B1134-B1141. [CrossRef]

44. Afshari, E.; Houreh, N.B. Performance analysis of a membrane humidifier containing porous metal foam as flow distributor in a PEM fuel cell system. Energy Convers. Manag. 2014, 88, 612-621. [CrossRef]

45. Yoon, Y.; Jo, Y.; Kim, H.S. Experimental investigation of liquid water droplet removal in a simulated polymer electrolyte membrane fuel cell gas channel with gas diffusion layer characteristics. J. Mech. Sci. Technol. 2014, 28, 5221-5230. [CrossRef]

46. Adroher, X.C.; Wang, Y. Ex situ and modeling study of two-phase flow in a single channel of polymer electrolyte membrane fuel cells. J. Power Sources 2011, 196, 9544-9551. [CrossRef]

47. Kim, M.; Kim, C.; Sohn, Y. Application of Metal Foam as a Flow Field for PEM Fuel Cell Stack. Fuel Cells 2019, 18, 123-128. [CrossRef]

48. Kim, M.; Kim, C.; Sohn, Y. A Study on Performance of Polymer Electrolyte Membrane Fuel Cell Using Metal Foam. Trans. Korean Hydrog. New Energy Soc. 2015, 26, 554-559. [CrossRef]

49. Dicks, A.L.; David, A.; Rand, J. Fuel Cell Systems Explained, 3rd ed.; John Wiley \& Sons Ltd: Hoboken, NJ, USA, 2018.

50. O'hayre, R.; Cha, S.W.; Colella, W.; Prinz, F.B. Fuel Cell Fundamentals, 3rd ed.; John Wiley \& Sons: Hoboken, NJ, USA, 2016.

(C) 2020 by the authors. Licensee MDPI, Basel, Switzerland. This article is an open access article distributed under the terms and conditions of the Creative Commons Attribution (CC BY) license (http://creativecommons.org/licenses/by/4.0/). 